\title{
Ergotamine-induced vasospastic ischemia mimicking arterial embolism: unusual case
}

\author{
Gürhan Adam, M.D., ${ }^{1}$ Tolga Kurt, M.D., ${ }^{2}$ Celal Çınar, M.D., ${ }^{3}$ Abdullah Sarıyıldırım, M.D., ${ }^{1}$ \\ Mustafa Resorlu, M.D., ${ }^{1}$ Fatma Uysal, M.D., ${ }^{1}$ Ali Ümit Yener, M.D., ${ }^{2}$ Sedat Özcan, M.D., ${ }^{2}$ \\ Mustafa Saçar, M.D., ${ }^{2}$ Hüseyin Özdemir, M.D. ${ }^{1}$
}

${ }^{1}$ Department of Radiology, Canakkale Onsekiz Mart University Faculty of Medicine, Canakkale;

${ }^{2}$ Department of Cardiovascular Surgery, Canakkale Onsekiz Mart University Faculty of Medicine, Canakkale;

${ }^{3}$ Department of Radiology, Ege University Faculty of Medicine, Izmir

\begin{abstract}
Ergotamine toxicity is an important and rare condition, including tachycardia, arterial spasm which occurring as a result of accidental overdosing or drug interactions. We assessed the consequences of delayed diagnosis of peripheral arterial vasoconstriction occurring after simultaneous macrolide use by a 35-year-old woman using an ergot-derived drug for migraine. Diagnosis of ergotamine intoxication begins with suspicion. Interventional radiologists and surgeons should be aware of this acute dangerous condition.
\end{abstract}

Key words: Acute arterial emboli; ergotamine; vasospasm.

\section{INTRODUCTION}

Ergot alkaloids are widely used drugs in the treatment and prophylaxis of migraine headache. Ergotamine-induced vasospastic ischemia is a rare, but important complication of these drugs including hypertension, tachycardia, and arterial spasm. ${ }^{[l]}$ The lower extremities are the most commonly involved part of the body and this condition may present as an acute arterial embolism that requiring endovascular intervention. Furthermore, delayed diagnosis can be caused of serious irreversible complications.

We know that several agents, such as macrolides may raise the level of serum ergotamines and its toxic effects. In this study, we assessed the consequences of delayed diagnosis of peripheral arterial vasoconstriction occurring after simulta-

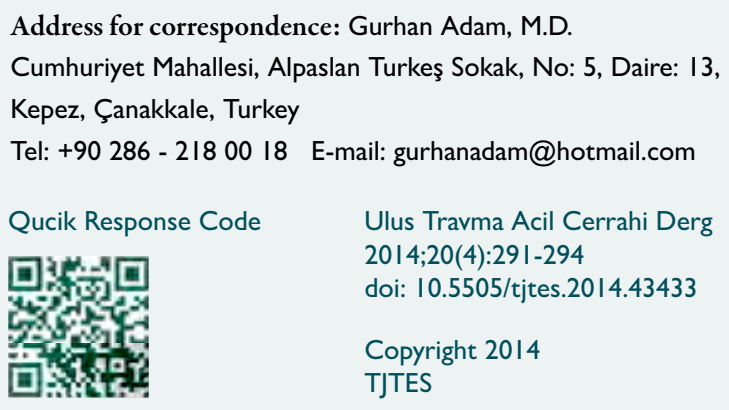

neous macrolide use by a 35-year-old woman taking an ergotamine-derived drug for migraine.

\section{CASE REPORT}

A 35-year-old woman presented to our emergency department with the complaint of worsening pain and pallor in the left foot that started 2 days before. The patient's history revealed that she had been a heavy smoker for 10 years and had received a single I $g$ dose of azithromycin due to a genital infection 4 days previously. In the left, peripheral pulses could not be measured at physical examination, and the foot was pale and sensitive. Wide loss of calibration and monophasic flow forms were observed in the left side arteries at color Doppler ultrasound. Acute arterial embolism was suspected, heparin was started at $1000 \mathrm{IU} /$ hour, and the patient was taken for emergency arterial embolectomy of the lower left extremity. During thrombectomy, surgeons recognized diffuse narrowed calibration of the femoral artery, but all the arteries were patent without thromboemboli. Angiography of the lower extremity was performed because of the no thrombotic material emerged from the distal arterial bed. Angiographic images revealed decreased calibration in the entire arterial system in the lower right extremity (Fig. I). Crural arteries on the left side could not be observed in some places, while the observed sections were finely calibrated. Normal calibration was seen in the proximal arteries on the left, embolectomized side. Right embolectomy was performed following development of similar symptoms on the right side. 

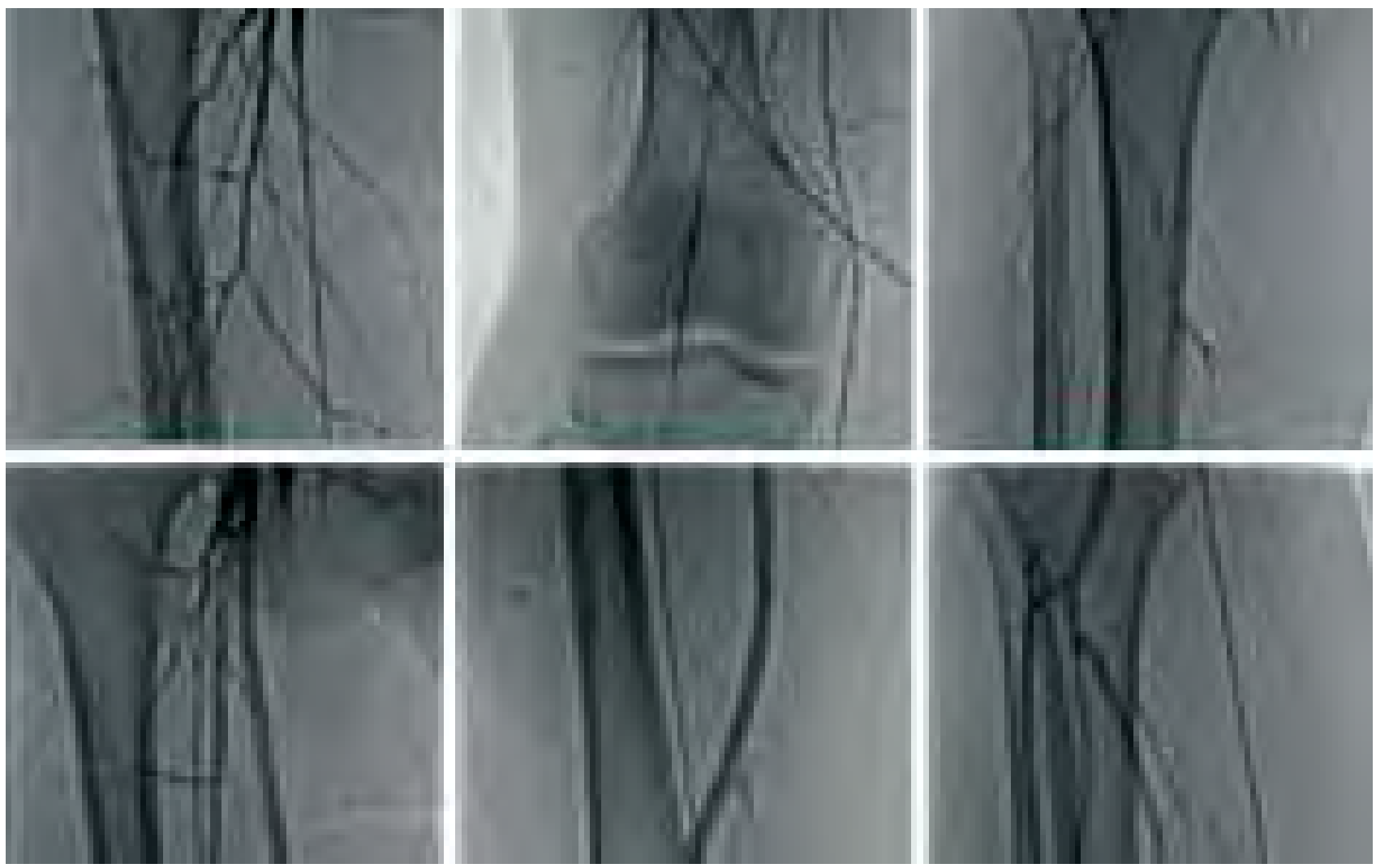

Figure 1. Angiography of the right lower extremity arteries demonstrate thread-like narrowing in the all lower arteries (upper series), after treatment of heparin and embolectomy, right sided angiography shows normal calibration of all arteries (lower series).

Ergot-induced arterial spasm was not considered at the beginning, because she did not explain this before angiography. However, detailed anamnesis revealed that she has had migraine and was on long-term ergotamine use in addition to azithromycin for 4 days ago. We suspected that the symptoms might be vasospastic in origin and related to ergotamine use, and ergotamine was stopped. Heparin at $1000 \mathrm{IU} /$ hour continued to be used for 7 days. Clinical findings improved, and vasospasm resolved completely at 5 th day control angiography (Fig. 2). She was informed about ergotamine-related symptoms that might occur and discharged. No problem was encountered at 6 months follow-up.

\section{DISCUSSION}

The toxicity level in patients using ergot alkaloids is estimated to be as low as $0.001-0.002 \% .{ }^{[2]}$ The vascular side-effects have been associated with ergotamine toxicity resulting from therapeutic doses in patients with oversensitivity, various drug interactions or overdosing. ${ }^{[3,4]}$ Our patient took ergotamine in a therapeutic dose, and a macrolide group drug was added to treatment due to urinary tract infection.

Vascular ischemia in ergotamine toxicity may lead to severely complicated conditions through alpha adrenergic and antiserotonergic activity and vasospasm and thrombus formation. Although the arteries of the lower extremities are most frequently affected, coronary, mesenteric, splenic, re- nal, and retinal arterial spasms have also been reported. ${ }^{[5,6]}$ Bilateral lower extremity arterial structures were affected in our patient.

In ergot intoxication, color Doppler ultrasound findings suggest diffuse spasm, in the form of loss of calibration, together with an increased flow rate in the arteries. Most patients therefore require angiographic examination. Diffuse and segmental spasm is observed in vascular structures at angiography. Findings are generally symmetrical and show that both lower extremities are affected..$^{[7]}$ Since ergot intoxication is rare, these non-specific clinical findings are inadequate for diagnosis. In that context, radiological findings in combination with clinical findings and deep anamnesis become significant. Conditions such as fever, sepsis, malnutrition, thyrotoxicosis, pregnancy, liver and kidney insufficiencies, coronary artery disease and peripheral vascular disease increase the toxic effects of ergotamine.$^{[8]}$ Drugs such as oral contraceptives, propranolol, xanthine derivatives, antiviral and antiretroviral agents and antibiotics that affect the metabolism of ergotamine in the liver (including erythromycin, clarithromycin, and ampicillin) may cause an increase in the effects of ergotamine. ${ }^{[7,9]}$

In addition, conditions such as Buerger's disease and Reynaud's phenomenon must be considered at diagnosis. These angiographic and clinical findings differ from ergotamine intoxication. ${ }^{[10]}$ 

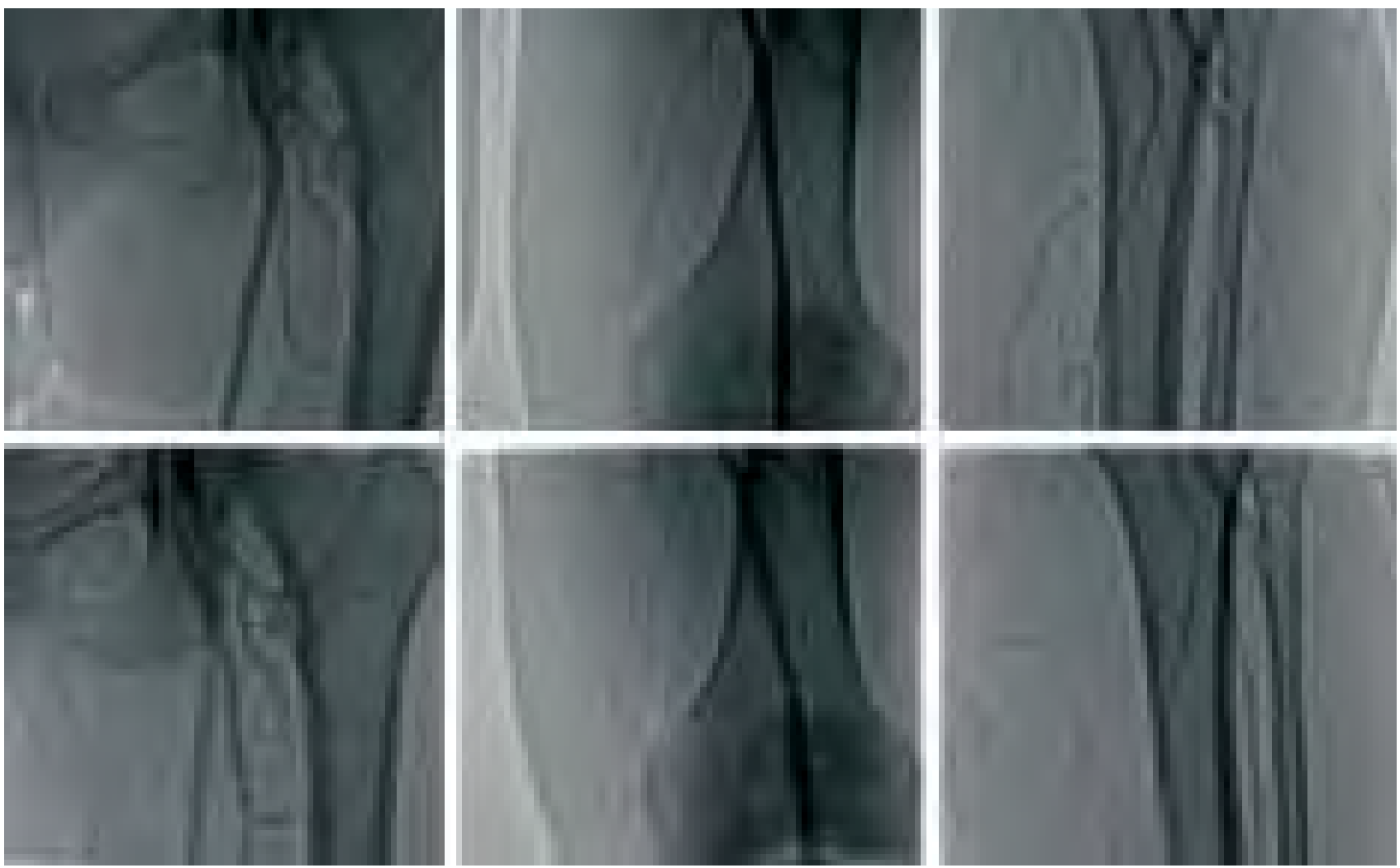

Figure 2. Angiography of the left lower extremity shows normal size of the superficial femoral artery, embolectomized side. The distal portions of the popliteal artery exhibit severe vasospasm (upper series). Angiographic findings of the left lower extremity arteries show normal calibration following treatment of heparin and embolectomy. Left sided angiography shows normal calibration of the all arteries (lower series).

Treatment of ergotamine toxicity diagnosed in the light of clinical and radiological findings begins with stopping the drug. Findings will generally be seen to improve. In resistant cases, however, treatment is planned with various vasodilator and anticoagulant drugs (nitroprusside, prazosin, tolazoline, thymoxamine $\mathrm{HCl}$, streptokinase, calcium channel blockers, the application of intra-arterial prostaglandin EI, intravenous heparin, nitroglycerin or intra-arterial nifedin). ${ }^{\left[{ }^{\prime I}\right]}$ Arterial spasm generally restricts and resolves itself with medical treatment. On rare occasions, medical treatment may be insufficient, in which case intra-arterial balloon dilation and surgery or chemical sympathectomy procedures may be regarded as effective. Peripheral balloon angioplasty, atherectomy and other procedures effective in resolving arterial spasm may lead to permanent damage in the arterial bed.

Our case presented with findings of acute arterial embolism. Since claudication was described as intermittent at anamnesis, acute chronic arterial blockage was considered, and ergotamine intoxication was not suspected. Loss of calibration in the lower extremity arteries at colored Doppler ultrasound was suggestive of vasospasm, but since ergotamine intoxication is rare it was not considered at diagnosis. Therefore, embolectomy was performed immediately for treatment of the ischemic condition of the patient's lower extremity. Detailed history revealed that she had been taking ergotamine for 3 years.
Peripheral balloon angioplasty, atherectomy and other procedures alongside medical treatment have been reported to eliminate vasospasm in patients diagnosed with ergotamine intoxication. However, since there is a risk of this causing permanent damage to normal arteries, their use is not primarily recommended in the absence of necrosis and gangrene. ${ }^{[7]}$ Consecutive embolectomies were performed due to the delay in diagnosing our patient.

Diagnosis of ergotamine intoxication begins with suspicion. Diagnosis can then be established by deepening anamnesis, particularly in patients not at risk of vascular diseases. Interventional radiologists and surgeons should be aware of this acute dangerous condition.

Conflict of interest: None declared.

\section{REFERENCES}

1. Kim MD, Lee G, Shin SW. Ergotamine-induced upper extremity ischemia: a case report. Korean J Radiol 2005;6:130-2. CrossRef

2. Paraskevopoulos JA, Teasdale DE, Cuschieri RJ. Severe reversible arterial spasm with ergotamine. Br J Clin Pract 1995;49:214.

3. Garcia GD, Goff JM Jr, Hadro NC, O'donnell SD, Greatorex PS. Chronic ergot toxicity: A rare cause of lower extremity ischemia. J Vasc Surg 2000;31:1245-7. CrossRef

4. Cervi E, Bonardelli S, Battaglia G, Gheza F, Maffeis R, Nodari F, et al. Upper limb artery segmental occlusions due to chronic use of ergota- 
mine combined with itraconazole, treated by thrombolysis. Thromb J 2011;9:13. CrossRef

5. Voyvodic F, Hayward M. Case report: upper extremity ischaemia secondary to ergotamine poisoning. Clin Radiol 1996;51:589-91. CrossRef

6. Dal Verme A, López E, Grinspon S, Fernández Pardal R, Mengia M, Mazzocchi O. Splenic infarction. Ergotism induced by ritonavir?. [Article in Spanish] Medicina (B Aires) 2012;72:475-7. [Abstract]

7. McKiernan TL, Bock K, Leya F, Grassman E, Lewis B, Johnson SA, et al. Ergot induced peripheral vascular insufficiency, non-interventional treatment. Cathet Cardiovasc Diagn 1994;31:211-4. CrossRef
8. Wells KE, Steed DL, Zajko AB, Webster MW. Recognition and treatment of arterial insufficiency from cafergot. J Vasc Surg 1986;4:8-15.

9. Fukui S, Coggia M, Goëau-Brissonnière O. Acute upper extremity ischemia during concomitant use of ergotamine tartrate and ampicillin. Ann Vasc Surg 1997;11:420-4. CrossRef

10. Pope JE. The diagnosis and treatment of Raynaud's phenomenon: a practical approach. Drugs 2007;67:517-25. CrossRef

11. Demir S, Akin S, Tercan F, Ariboğan A, Oğuzkurt L. Ergotamine-induced lower extremity arterial vasospasm presenting as acute limb ischemia. Diagn Interv Radiol 2010;16:165-7.

\section{OLGU SUNUMU - ÖZET}

\section{Arteriyel emboliyi taklit eden ergotamine bağlı vazospastik iskemi: Nadir bir olgu \\ Dr. Gürhan Adam, ${ }^{1}$ Dr. Tolga Kurt, ${ }^{2}$ Dr. Celal Çınar, ${ }^{3}$ Dr. Abdullah Sarıyıldırım, ${ }^{1}$ Dr. Mustafa Resorlu, ${ }^{1}$ Dr. Fatma Uysal, ${ }^{1}$ Dr. Ali Ümit Yener, ${ }^{2}$ Dr. Sedat Özcan, ${ }^{2}$ Dr. Mustafa Saçar, ${ }^{2}$ Dr. Hüseyin Özdemir ${ }^{1}$}

${ }^{1}$ Çanakkale Onsekiz Mart Üniversitesi Tıp Fakültesi, Radyoloji Anabilim Dalı, Çanakkale;

${ }^{2}$ Çanakkale Onsekiz Mart Üniversitesi Tıp Fakültesi, Kardiyovasküler Cerrahi Anabilim Dalı, Çanakkale;

${ }^{3}$ Ege Üniversitesi Tıp Fakültesi, Radyoloji Anabilim Dalı, İzmir

Ergotamin zehirlenmesi, yanlışlıkla aşırı doz alımına ya da ilaç etkileşimleri sonucunda ilaç etkinliğinin artmasıyla ortaya çıkan taşikardi, arteriyel spazm gibi bulguları olan ciddi ve nadir bir durumdur. Bu yazıda Migren için bir ergot türevi ilaç kullanan 35 yaşındaki olgunun, eşzamanlı makrolid kullanımın oluşturduğu, periferik arteriyel vazokonstrüksiyonun gecikmiş tanı sonuçlarını değerlendirdik.

Anahtar sözcükler: Anjiografi; ergotamine; iskemi.

Ulus Travma Acil Cerrahi Derg 2014;20(4):291-294 doi: 10.5505/tjtes.2014.43433 